\title{
Commentary: To be or not to be: The guidelines are the question
}

Alice Le Huu, MD, and Joseph S. Coselli, MD

From the Division of Cardiothoracic Surgery, Michael E. DeBakey Department of Surgery, Baylor College of Medicine, Houston, Tex; Department of Cardiovascular Surgery, Texas Heart Institute, Houston, Tex; and CHI St Luke's Health-Baylor St Luke's Medical Center, Houston, Tex.

Disclosures: Authors have nothing to disclose with regard to commercial support.

Received for publication Sept 17, 2018; accepted for publication Sept 17, 2018; available ahead of print Nov 7 , 2018.

Address for reprints: Joseph S. Coselli, MD, One Baylor Plaza, BCM 390, Houston, TX 77030 (E-mail: jcoselli@ bcm.edu).

J Thorac Cardiovasc Surg 2019;157:1746-7

$0022-5223 / \$ 36.00$

Copyright (c) 2018 by The American Association for Thoracic Surgery

https://doi.org/10.1016/j.jtcvs.2018.09.058

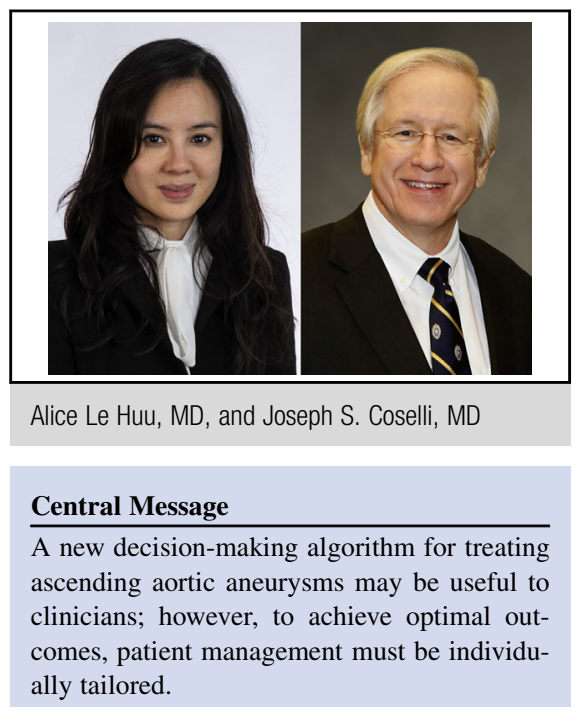

See Article page 1733 .
Despite significant gains in elucidating the physiopathology of ascending aortic aneurysms, in conjunction with improvements in surgical technique, managing this disease remains challenging. Of utmost importance to the patient is the threshold at which operative intervention is warranted. For many patients, current American and European guidelines recommend surgical repair of an ascending aorta or aortic sinus measuring $\geq 5.5 \mathrm{~cm} .{ }^{1,2}$ This threshold is lower for patients with a strong family history of aneurysm, a bicuspid valve, or a connective tissue disorder. In these clinical scenarios, intervention appears warranted at aortic diameters between 4 and $5 \mathrm{~cm}^{3}$ However, the guidelines for operative management of an aortic aneurysm with concomitant bicuspid valve have become increasingly controversial because studies suggest that early intervention on an aorta $<4.5 \mathrm{~cm}$ does not confer a survival advantage. ${ }^{4,5}$

Dr Elefteriades and his team at Yale have been instrumental in the development of the existing guidelines for thoracic aortic disease. ${ }^{6}$ In their latest endeavor, they have created a decision-making algorithm for managing ascending aortic aneurysms. This new algorithm is based on the premise that previous guidelines are too conservative in recommending repair of an aortic aneurysm at a diameter of $5.5 \mathrm{~cm}$.

The team separated patients with ascending aortic aneurysms into 3 distinct categories: those with aneurysms $\geq$ $5.0 \mathrm{~cm}$, those with aneurysms 4.0 to $4.9 \mathrm{~cm}$ and risk factors, and those with aneurysms 4.0 to $4.9 \mathrm{~cm}$ and no risk factors. Surgery was recommended for the patients with an aortic diameter $\geq 5.0 \mathrm{~cm}$, rather than $5.5 \mathrm{~cm}$ as previously established guidelines suggest. Additionally, their algorithm establishes that patients with unexplained chest pain, which was classified as a risk factor, should be triaged to surgery when ascending aortic diameter is greater than $4.0 \mathrm{~cm}$, along with patients with other risk factorsfamily history, connective tissue disorder, and bicuspid aortic valve. Two observations were made regarding the decision-making algorithm: that it correctly identified patients at risk for an aortic event, and that among patients whom the algorithm triaged to surgery, those who did not undergo surgery had significantly worse outcomes than those who did undergo it. The authors concluded that consideration should be given to changing the threshold diameter for operating on ascending aortic aneurysms from $5.5 \mathrm{~cm}$ to $5 \mathrm{~cm}$.

In an effort to develop a new algorithm, Dr Elefteriades and his team have undertaken the formidable task of extensively analyzing an enormous dataset. ${ }^{6}$ Developing a simplified decision-making tool to address an exceedingly complex clinical pathology is particularly challenging. In clinical settings, the decision to operate at a smaller aortic diameter requires considering several factors, including genetic syndromes, family history, any previous cardiac or aortic surgery, age, and patient size. All of these factors substantially alter the development of aortic aneurysms, but unfortunately, their related risk is difficult to fully elucidate. Furthermore, the team's data suggest that a leftward shift of operative indications for aortic aneurysms may be warranted. However, a change in the guidelines must be tempered by the knowledge that operative results obtained at smaller centers may not be comparable to those at Yale. Although a framework can guide operative management, patients must be evaluated in an 
individual and institutional context to achieve optimal clinical outcomes.

\section{References}

1. Erbel R, Aboyans V, Boileau C, Bossone E, Bartolomeo RD, Eggebrecht H, et al; ESC Committee for Practice Guidelines. 2014 ESC guidelines on the diagnosis and treatment of aortic diseases: document covering acute and chronic aortic diseases of the thoracic and abdominal aorta of the adult. The Task Force for the Diagnosis and Treatment of Aortic Diseases of the European Society of Cardiology (ESC). Eur Heart J. 2014;35:2873-926.

2. Hiratzka LF, Bakris GL, Beckman JA, Bersin RM, Carr VF, Casey DE Jr, et al. 2010 ACCF/AHA/AATS/ACR/ASA/SCA/SCAI/SIR/STS/SVM guidelines for the diagnosis and management of patients with thoracic aortic disease: a report of the American College of Cardiology Foundation/American Heart Association task force on practice guidelines, American Association for Thoracic Surgery,
American College of Radiology, American Stroke Association, Society of Cardiovascular Anesthesiologists, Society for Cardiovascular Angiography and Interventions, Society of Interventional Radiology, Society of Thoracic Surgeons, and Society for Vascular Medicine. Circulation. 2010;121:e266-369.

3. Elefteriades JA. Natural history of thoracic aortic aneurysms: indications for surgery, and surgical versus nonsurgical risks. Ann Thorac Surg. 2002;74: S1877-80.

4. Masri A, Kalahasti V, Alkharabsheh S, Svensson LG, Sabik JF, Roselli EE, et al Characteristics and long-term outcomes of contemporary patients with bicuspid aortic valves. J Thorac Cardiovasc Surg. 2016;151:1650-9.e1.

5. Abdulkareem N, Soppa G, Jones S, Valencia O, Smelt J, Jahangiri M. Dilatation of the remaining aorta after aortic valve or aortic root replacement in patients with bicuspid aortic valve: a 5-year follow-up. Ann Thorac Surg. 2013;96:43-9.

6. Saeyeldin A, Zafar MA, Li Y, Tanweer M, Abdelbaky M, Gryaznov A, et al. Decision-making algorithm for ascending aortic aneurysms: effectiveness in clinical application? J Thorac Cardiovasc Surg. 2019;157:1733-45.

Access to The Journal of Thoracic and Cardiovascular Surgery Online is reserved for print subscribers!

Full-text access to The Journal of Thoracic and Cardiovascular Surgery Online is available for all print subscribers. To activate your individual online subscription, please visit The Journal of Thoracic and Cardiovascular Surgery Online, point your browser to http://www.mosby.com/jtcvs, follow the prompts to activate your online access, and follow the instructions. To activate your account, you will need your subscriber account number, which you can find on your mailing label (note: the number of digits in your subscriber account number varies from 6 to 10 ). See the example below in which the subscriber account number has been circled:

\section{Sample mailing label}

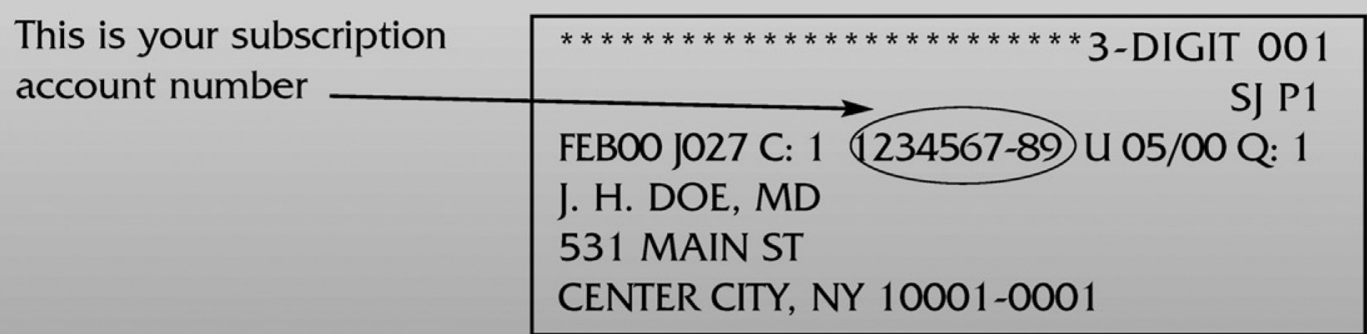

Personal subscriptions to The Journal of Thoracic and Cardiovascular Surgery Online are for individual use only and may not be transferred. Use of The Journal of Thoracic and Cardiovascular Surgery Online is subject to agreement to the terms and conditions as indicated online. 